\title{
Correction to: Evaluating the efficacy and safety of human anti-SARS-CoV-2 convalescent plasma in severely ill adults with COVID-19: A structured summary of a study protocol for a randomized controlled trial
}

Christina M. Eckhardt*, Matthew J. Cummings, Kartik N. Rajagopalan, Sarah Borden, Zachary C. Bitan, Allison Wolf, Alex Kantor, Thomas Briese, Benjamin J. Meyer, Samuel D. Jacobson, Dawn Scotto, Nischay Mishra, Neena M. Philip, Brie A. Stotler, Joseph Schwartz, Beth Shaz, Steven L. Spitalnik, Andrew Eisenberger, Eldad A. Hod, Jessica Justman, Ken Cheung, W. Ian Lipkin and Max R. O'Donnell

Correction to: Trials 21, 499 (2020)

https://doi.org/10.1186/s13063-020-04422-y

Following publication of the original article [1], the authors identified an error in the author name of Andrew Eisenberger.

The incorrect author name is: Andrew Eisenberg

The correct author name is: Andrew Eisenberger

The author group has been updated above and the original article [1] has been corrected.

Published online: 16 June 2020

\section{Reference}

1. Eckhardt, et al. Evaluating the efficacy and safety of human anti-SARS-CoV-2

convalescent plasma in severely ill adults with COVID-19: A structured

summary of a study protocol for a randomized controlled trial. Trials. 2020;

21:499. https://doi.org/10.1186/s13063-020-04422-y.

The original article can be found online at https://doi.org/10.1186/s13063-

020-04422-y.

* Correspondence: cme2113@cumc.columbia.edu

Columbia University Medical Center, New York, USA

(c) The Author(s). 2020 Open Access This article is licensed under a Creative Commons Attribution 4.0 International License, which permits use, sharing, adaptation, distribution and reproduction in any medium or format, as long as you give appropriate credit to the original author(s) and the source, provide a link to the Creative Commons licence, and indicate if changes were made. The images or other third party material in this article are included in the article's Creative Commons licence, unless indicated otherwise in a credit line to the material. If material is not included in the article's Creative Commons licence and your intended use is not permitted by statutory regulation or exceeds the permitted use, you will need to obtain permission directly from the copyright holder. To view a copy of this licence, visit http://creativecommons.org/licenses/by/4.0/. The Creative Commons Public Domain Dedication waiver (http://creativecommons.org/publicdomain/zero/1.0/) applies to the data made available in this article, unless otherwise stated in a credit line to the data. 